\title{
A Comparison Effect of Copper Nanoparticles versus Copper Sulphate on Juvenile Epinephelus coioides: Growth Parameters, Digestive Enzymes, Body Composition, and Histology as Biomarkers
}

\author{
Tao Wang, Xiaohua Long, Yongzhou Cheng, Zhaopu Liu, and Shaohua Yan \\ Jiangsu Provincial Key Laboratory of Marine Biology, College of Resources and Environmental Sciences, \\ Nanjing Agricultural University, Nanjing 210095, China \\ Correspondence should be addressed to Xiaohua Long; longxiaohua2014@126.com
}

Received 23 December 2014; Revised 2 February 2015; Accepted 18 February 2015

Academic Editor: Marián Brestič

Copyright (C) 2015 Tao Wang et al. This is an open access article distributed under the Creative Commons Attribution License, which permits unrestricted use, distribution, and reproduction in any medium, provided the original work is properly cited.

\begin{abstract}
Copper nanoparticles (Cu-NPs) are components in numerous commercial products, but little is known about their potential hazard in the marine environments. In this study the effects of $\mathrm{Cu}-\mathrm{NPs}$ and soluble $\mathrm{Cu}$ on juvenile Epinephelus coioides were investigated. The fish were exposed in triplicate to control, 20 or $100 \mu \mathrm{g} \mathrm{Cu} \mathrm{L}^{-1}$ as either copper sulphate $\left(\mathrm{CuSO}_{4}\right)$ or $\mathrm{Cu}-\mathrm{NPs}$ for 25 days. The growth performance decreased with increasing $\mathrm{CuSO}_{4}$ or $\mathrm{Cu}-\mathrm{NPs}$ dose, more so in the $\mathrm{CuSO}_{4}$ than $\mathrm{Cu}-\mathrm{NPs}$ treatment. Both forms of $\mathrm{Cu}$ exposure inhibited activities of digestive enzymes (protease, amylase, and lipase) found in liver, stomach, and intestine. With an increase in $\mathrm{CuSO}_{4}$ and $\mathrm{Cu}-\mathrm{NPs}$ dose, crude protein and crude lipid decreased, but ash and moisture increased, more so in the $\mathrm{CuSO}_{4}$ than $\mathrm{Cu}-\mathrm{NPs}$ treatment. The $\mathrm{Cu}-\mathrm{NPs}$ treatment caused pathologies in liver and gills, and the kinds of pathologies were broadly of the same type as with $\mathrm{CuSO}_{4}$. With an increase in $\mathrm{CuSO}_{4}$ or $\mathrm{Cu}-\mathrm{NPs}$ dose, the total polyunsaturated fatty acids decreased, but total monounsaturated fatty acids and total saturated fatty acids increased compared to control. Overall, these data showed that $\mathrm{Cu}-\mathrm{NPs}$ had a similar type of toxic effects as $\mathrm{CuSO}_{4}$, but soluble $\mathrm{Cu}$ was more toxic than Cu-NPs.
\end{abstract}

\section{Introduction}

The contamination of aquatic ecosystems by metals is one of the main environmental issues today [1]. In the last decade, the advance of nanotechnology fueled fast growth of the nanotoxicology research and the need for information on potential hazards of this technology in aquatic environments $[1,2]$.

Copper nanoparticles (Cu-NPs) are one of the most used nanomaterials due to their antibacterial and other properties [3], used for example, in textiles, food storage containers, home appliances, paints, food supplements and so on [4]. Production and use of Cu-NPs likely result in their release into aquatic environments and can lead to unexpected hazards to aquatic organisms $[1,5,6]$. In addition, $\mathrm{Cu}-\mathrm{NPs}$ could be accumulated in aquatic organisms and transferred to higher trophic levels, representing a health hazard to animals and humans $[5,7]$.
Currently, concerns have been raised about the effects of $\mathrm{Cu}-\mathrm{NPs}$ on fish $[2,3,8]$ and also about the sublethal effects of NPs on different body systems of fish $[8,9]$. However, the majority of the published studies focused on $\mathrm{Cu}-\mathrm{NPs}$ regarding a lethal dose [8], accumulation [5,7], stress response $[3,8]$, osmoregulation $[6,7]$, and pathology [2]. To our knowledge, the effects of nanometals on digestive enzyme activities, whole-body composition, and fatty acid composition are poorly understood. Furthermore, toxicity thresholds can be rather variable in different species [9-11], and little attention has been given so far to marine teleosts.

Epinephelus coioides (grouper), a protogynous hermaphroditic fish, is widely cultured in China and Southeast Asian countries because of its excellent seafood quality and its high market value [12]. Currently, Epinephelus coioides species are mainly cultured in floating net cages and earthen ponds in the natural environments that can easily be affected by 
environment pollution given that discharge of $\mathrm{Cu}-\mathrm{NPs}$ in the aquatic environment is inevitable [2]. However, as far as we know, there is paucity of data about toxicity of $\mathrm{Cu}-\mathrm{NPs}$ on Epinephelus coioides.

In aquaculture production, the inappropriate management often promotes proliferation of diseases in aquatic organisms [13]. Another problem related to aquaculture is the excessive growth of phytoplankton, particularly bluegreen algae [14]. Copper sulphate $\left(\mathrm{CuSO}_{4}\right)$ is employed to control diseases and algae in aquaculture facilities [15]. Copper is an essential micronutrient required for the various functions in biological systems, such as cell structure and enzyme activities of fish $[16,17]$. However, excessive $\mathrm{Cu}$ in the aquatic environment can be toxic $[7,18]$. It has been reported that $\mathrm{CuSO}_{4}$ can induce endocrine disruption and change metabolic rates $[19,20]$, swimming behavior $[21$, 22], immunological function [2, 8], enzyme activities [8], tissue histology [2, 20], and fatty acid composition [23, 24]. Recently, we found that $\mathrm{CuSO}_{4}$ exposure could significantly influence oxidative stress, $\mathrm{Na}^{+} / \mathrm{K}^{+}$-ATPase activity, and cell apoptosis in the liver of juvenile Epinephelus coioides [6]. Nevertheless, the physiology effects after Epinephelus coioides exposure to $\mathrm{CuSO}_{4}$ are poorly understood.

In this study, the main goal was to evaluate the effects of $\mathrm{Cu}-\mathrm{NPs}$ and $\mathrm{CuSO}_{4}$ on growth parameters, activities of the digestive enzymes (protease, amylase, and lipase), wholebody composition, fatty acid composition, and histology of juvenile Epinephelus coioides. Results of this study provide an insight into the toxicity mechanisms of $\mathrm{Cu}-\mathrm{NPs}$ compared with $\mathrm{CuSO}_{4}$, aiming to propose margins for a safe use of $\mathrm{CuSO}_{4}$ in fish culture.

\section{Materials and Methods}

2.1. Experimental Design. Juvenile Epinephelus coioides $(n=$ 800) were obtained from Shenzhen Dongfang Technology Co., Ltd. China and transferred to indoor tanks for 15 days to acclimate prior to the toxicity assay. During the acclimation period, the juveniles were fed once daily (at 8 am) with commercial feed. After accumulation, selected healthy juveniles ( $n=525$, average weight $3.1 \pm 0.2 \mathrm{~g}$ ) were randomly divided into 15 blue plastic tanks ( 35 fish per tank, the density approximately $1.0 \mathrm{~g}$ fish $\mathrm{L}^{-1}$ ) containing $100 \mathrm{~L}$ of simulated seawater. The simulated seawater was made by adding sea salt (purchased from Qingdao Universal Aquaculture Company, China) to the aerated tap water [12].

Three tanks per treatment were randomly allocated and fish were exposed in triplicate to control (no added $\mathrm{Cu}$ ), $20 \mu \mathrm{g} \mathrm{Cu} \mathrm{L}^{-1}$ or $100 \mu \mathrm{g} \mathrm{Cu} \mathrm{L}^{-1}$ either as $\mathrm{CuSO}_{4} \cdot 5 \mathrm{H}_{2} \mathrm{O}$ or $\mathrm{Cu}-$ NPs for 25 days using a semistatic exposure regime (50\% water change every $12 \mathrm{~h}$ with redosing after each change). The low concentration of $20 \mu \mathrm{g} \mathrm{Cu} \mathrm{L}^{-1} \mathrm{Cu}$ was selected because it reflects the actual environmental concentration [7]. The high $\mathrm{Cu}$ concentration $\left(100 \mu \mathrm{g} \mathrm{Cu} \mathrm{L}^{-1}\right)$ was selected because this concentration may be found in some areas with intensive manufacturing industries, agricultural and mining activities, and municipal waste depositions [25]. Water samples were taken before and after each water change and were analyzed for $\mathrm{pH}$, temperature, salinity, dissolved oxygen (tested by YSI
556MPS, USA), total ammonium (by Nessler's reagent spectrophotometry), water hardness ( $\mathrm{Ca}$ and $\mathrm{Mg}$ ), and $\mathrm{Cu}$ (trace elements were measured by an Inductively Coupled Plasma Optical Emission Spectrometer, ICP-OES, Optima 7000, PerkinElmer, USA). As there were no significant differences (ANOVA, $P \leq 0.05$ ) among any tanks in water quality or $\mathrm{Cu}$ treatment concentration, data were pooled and were $\mathrm{pH}$ $8.1 \pm 0.1$, water temperature $24 \pm 0.5^{\circ} \mathrm{C}$, salinity $27.5 \pm 0.5 \mathrm{~g} \mathrm{~L}^{-1}$ $(\mathrm{w} / \mathrm{v})$, total ammonium $0.15 \pm 0.05 \mathrm{mg} \mathrm{L}^{-1}$, and total hardness $\left(\mathrm{mg} \mathrm{CaCO} \mathrm{L}^{-1}\right), 405 \pm 4$. Continuous aeration was used to ensure dissolved oxygen above $5 \mathrm{mg} \mathrm{L}^{-1}$. The photoperiod was $12 \mathrm{~h}$ light: $12 \mathrm{~h}$ dark. The actual concentrations of $\mathrm{Cu}$ in the seawater were $2.3 \pm 0.1,21.9 \pm 1.4,102.5 \pm 3.1,20.3 \pm 2.8$, and $101.2 \pm 2.1 \mu \mathrm{g} \mathrm{L}^{-1}$ for the control, 20 and $100 \mu \mathrm{g} \mathrm{Cu} \mathrm{L}^{-1}$ as $\mathrm{CuSO}_{4}$, and 20 and $100 \mu \mathrm{g} \mathrm{Cu} \mathrm{L}^{-1}$ as Cu-NPs treatments, respectively. During the experimental, no fish mortality was observed.

To minimize the influence of hunger throughout the experiment (a requirement in animal husbandry) [17], fish were hand-fed commercial diet (Fish Po, imported from Japan, containing $54 \% \mathrm{w} / \mathrm{w}$ protein and $3.0 \pm 0.12 \mu \mathrm{g} \mathrm{Cu} \mathrm{g}^{-1}$ ) twice daily ( $8 \mathrm{am}$ and $4 \mathrm{pm}$ ) at a rate of $2-2.5 \% \mathrm{w} / \mathrm{w}$ fresh body mass each time [12] for 25 days. Feeding was done after each water change, but prior to $\mathrm{Cu}$ redosing to minimize the risk of ingestion of $\mathrm{Cu}-\mathrm{NPs}$ during feeding. Food was eaten within 5 minutes, with no food wasted.

2.2. Stock Solutions and Dosing. Stock solutions of $\mathrm{CuSO}_{4}$ and suspensions of $\mathrm{Cu}-\mathrm{NPs}$ were prepared and characterized as described in detail in our previous report [6] using the same stocks. Briefly, powder form of $\mathrm{Cu}$-NPs was purchased from Shanghai Aladdin Co., Ltd. China (manufacturer's information: particles $10-30 \mathrm{~nm}$; purity 99.9\%). A fresh $50-$ $\mathrm{mL} \mathrm{Cu}-\mathrm{NPs}$ stock solution of $1.0 \mathrm{~g} \mathrm{Cu} \mathrm{L}^{-1}$ was prepared at 8 pm daily by dispersing the nanoparticles in ultrapure water (Millipore, ion free and unbuffered), sonicated for $30 \mathrm{~min}$, and stirred for $1 \mathrm{~h}$ at room temperature. Primary particle sizes of the $\mathrm{Cu}-\mathrm{NPs}$ were measured manually from micrographs obtained using transmission electron microscopy (TEM, JEOL JEM-2100, Japan). The primary particle diameters of $\mathrm{Cu}-\mathrm{NPs}$ in stock suspensions were $85 \pm 29 \mathrm{~nm}$ (mean \pm S.E.M., $n=62$ particles). According to the method of Sovová et al. [26], the particle size distributions of $\mathrm{Cu}-\mathrm{NPs}$ in stock suspensions prepared as described above were measured by nanoparticle tracking analysis (NTA, NanoSight $\mathrm{LM}_{10}$ ) in $20 \mathrm{mg} \mathrm{L}^{-1}$ dilutions to avoid saturating the instrument. Dilutions of stock suspensions to $20 \mathrm{mg} \mathrm{L}^{-1}$ gave sufficient particle tracks ( $>100$ tracks per sample) to provide reproducible data of particle size distribution in the stock suspensions. The stock suspensions were observed to contain a normal distribution of particle sizes, ranging from individual $\mathrm{Cu}-\mathrm{NPs}$ of 0 to $30 \mathrm{~nm}$ to larger particles, almost certainly $\mathrm{Cu}-\mathrm{NPs}$ aggregates $>80 \mathrm{~nm}$. The mean diameter of aggregates in the suspension was $210 \pm 130 \mathrm{~nm}$ (mean \pm S.E.M., $n=3$ ).

A stock solution containing $1 \mathrm{~g} \mathrm{Cu} \mathrm{L}^{-1}$ as $\mathrm{CuSO}_{4}$ was prepared by dissolving $3.929 \mathrm{~g} \mathrm{CuSO} \cdot 5 \mathrm{H}_{2} \mathrm{O}$ in $1 \mathrm{~L}$ of ultrapure water (Millipore, ion free and unbuffered). The $\mathrm{CuSO}_{4}$ stock solution was used to dose the tanks throughout the 25-day 
exposure. Dosing of all treatments was carried out following the water change and again the following morning after a subsequent water change.

2.3. Fish Sampling. Fish from each tank were weighed at the beginning and end of experiment. Fish were not fed for $24 \mathrm{~h}$ before sampling [17]. Six fish were randomly taken from each tank and dissected on an ice tray. The whole liver, stomach, and intestine were removed; fat was cleaned and flushed by normal saline solution (salinity $8.6 \mathrm{~g} \mathrm{~L}^{-1}, 4^{\circ} \mathrm{C}$ ) and placed into a centrifuge tube (tissues from three out of six fish from each tank were combined) and stored at $-70^{\circ} \mathrm{C}$ for analyzing digestive enzyme activities; the other three fish from each replicate were used for the analysis of fatty acid composition. The remaining fish from each tank were collected for analysis of whole-body composition and for histological observation. For histological observation, the left lobe of liver and the second gill arch on the left were removed and fixed in $10 \%$ $\mathrm{v} / \mathrm{v}$ buffered formal saline $(100 \mathrm{~mL} 40 \% \mathrm{v} / \mathrm{v}$ formaldehyde, $6.5 \mathrm{~g} \mathrm{NaH}_{2} \mathrm{PO}_{4}$ (anhydrous), $4 \mathrm{~g} \mathrm{NaH}_{2} \mathrm{PO}_{4} \cdot \mathrm{H}_{2} \mathrm{O}$, diluted to $1 \mathrm{~L}$ with distilled water, $\mathrm{pH} 7.2$ ).

2.4. Digestive Enzyme Quantification. The total soluble protein content was measured in diluted homogenates by Bradford's method [27] using bovine serum albumin as a standard. Total protease activity was measured according to the method of Gui et al. [28], using casein as substrate with Folinphenol reagent. Amylase and lipase activities were measured using kits purchased from Nanjing Jiancheng Bioengineering Research Institute of China [29]. The unit of protease activity was defined as the amount of enzyme needed to catalyze the formation of $1 \mu \mathrm{g}$ of tyrosine per $1 \mathrm{~min}$ at $40^{\circ} \mathrm{C}$. The unit of amylase activity was defined as $10 \mathrm{mg}$ starch hydrolyzed with the substrate per $\mathrm{mg}$ protein in tissue during $30 \mathrm{~min}$ at $37^{\circ} \mathrm{C}$. The unit of lipase activity was estimated as consumption of $1 \mu \mathrm{mol}$ substrate (triglyceride) during $1 \mathrm{~min}$ at $37^{\circ} \mathrm{C}$ per $\mathrm{g}$ protein in tissue.

2.5. Determination of Whole-Body Composition. The fish whole-body samples were freeze-dried and homogenized prior to chemical analysis. Moisture, crude protein, crude fat, and ash contents were determined according to the standard methods [30]. Moisture content was analyzed using a Craft stove at $105^{\circ} \mathrm{C}$ to a constant weight. Crude protein content was determined by measuring nitrogen $(\mathrm{N} \times 6.25)$ using the Kjeldahl method. Crude fat content was measured using a micro Soxhlet Foss Soxtec Avanti (Soxtec Avanti 2050 Auto System, Foss Tecator AB, Höganas, Sweden). Ash content was determined by heating the samples in a muffle furnace at $550^{\circ} \mathrm{C}$ for $12 \mathrm{~h}$.

2.6. Determination of Fatty Acids Composition. The lipids from whole-body of juvenile Epinephelus coioides were extracted with a chloroform: methanol $(2: 1 \mathrm{v} / \mathrm{v})$ mixture by method of Dubois et al. [31] and esterified with 14\% (w/v) boron trifluoride $\left(\mathrm{BF}_{3}\right)$ in methanol according to Yoshioka et al. [32]. The samples were then analyzed using a Shimadzu GC-201 gas chromatograph (Shimadzu Co., Kyoto, Japan) in a cross-linked $5 \%$ phenylmethyl silicone gum phase column $\left(30 \mathrm{~m} \times 0.32 \mathrm{~mm}\right.$ i.d. $\times 0.25 \mathrm{~mm}$ film thickness; $\mathrm{N}_{2}$ as the carrier gas), equipped with flame ionization detection. The injector and detector temperatures were set at $250^{\circ} \mathrm{C}$. The column oven temperature was kept at $100^{\circ} \mathrm{C}$ for $3 \mathrm{~min}$, raised to $180^{\circ} \mathrm{C}$ at the rate of $10^{\circ} \mathrm{C} \mathrm{min}^{-1}$, and then raised to $240^{\circ} \mathrm{C}$ at $3^{\circ} \mathrm{C} \mathrm{min}^{-1}$. The relative quantity of each fatty acid present was determined by measuring the area under the chromatograph peak corresponding to that fatty acid.

2.7. Histology. Histological analyses followed the standard techniques [33]. Briefly, the samples were dehydrated in rising concentrations of ethanol, cleared in xylene, infiltrated with rising concentrations of liquid paraffin wax at $58^{\circ} \mathrm{C}$, and later embedded in paraffin blocks. The sections were cut at 7 - $\mu$ m-thick with a Rotary microtome (MT-1090A, India), and stained using hematoxylin and eosin (H\&E). Stained sections were observed by light microscopy (Leica DM750, Switzerland).

2.8. Calculations and Statistical Analysis. The relative weight gain rate (WG, \%), specific growth rate $\left(\mathrm{SGR}, \% \mathrm{~d}^{-1}\right)$, food conversion ratio (FCR), and protein efficiency ratio (PER) were calculated as follows $[28,34]$ :

$$
\begin{gathered}
\mathrm{WG}(\%)=\frac{\left[\left(w_{t}-w_{0}\right) \times 100\right]}{w_{0}}, \\
\mathrm{SGR}_{\mathrm{d}}\left(\% \text { day }^{-1}\right)=\left(\frac{\left(\ln \left(w_{t}\right)-\ln \left(w_{0}\right)\right)}{t}\right) \times 100, \\
\mathrm{FCR}=\frac{C}{\left(w_{t}-w_{0}\right)}, \\
\operatorname{PER}=\frac{\left(w_{t}-w_{0}\right)}{(C \times \text { protein content })},
\end{gathered}
$$

where $w_{t}$ and $w_{0}$ are the final and initial wet body weight (g) of juvenile Epinephelus coioides, respectively, $t$ is the duration of experiment ( 25 days), and $C$ is the mean total food intake on a dry weight basis [35]. The diet contained 54\% w/w protein.

Experimental data were analysed by one-way analysis of variance (ANOVA) using SPSS (18.0; SPSS Inc., Chicago, IL, USA) for Windows. Tukey's test was used to compare differences among treatments. The $P \leq 0.05$ was considered statistically significant. All data were presented as means \pm S.E.M. (standard error of the mean).

\section{Results}

3.1. Growth Parameters. With an increase in $\mathrm{CuSO}_{4}$ or $\mathrm{Cu}-$ NPs concentration, WG, SGR $\mathrm{d}_{\mathrm{d}}$, and PER were decreased compared to control, more so in the $\mathrm{CuSO}_{4}$ than $\mathrm{Cu}$ NPs treatments. In contrast, FCR increased with increasing $\mathrm{CuSO}_{4}$ or $\mathrm{Cu}-\mathrm{NPs}$ dose, with the highest FCR at $100 \mu \mathrm{g} \mathrm{Cu} \mathrm{L}{ }^{-1}$ as $\mathrm{CuSO}_{4}$ (Table 1).

3.2. Digestive Enzyme Activities. The activities of protease, amylase, and lipase found in liver, stomach, and intestine were 
TABLE 1: Effect of Cu-NPs and $\mathrm{CuSO}_{4}$ on weight gain rate (WG, \%), specific growth rate (SGR \% $\mathrm{d}^{-1}$ ), food conversion ratio (FCR), and protein efficiency ratio (PER) of juvenile Epinephelus coioides after 25-day exposure.

\begin{tabular}{lccccc}
\hline Control & $\begin{array}{c}20 \mu \mathrm{g} \mathrm{Cu} \mathrm{L}^{-1} \\
\text { as CuSO}\end{array}$ & $\begin{array}{c}20 \mu \mathrm{g} \mathrm{Cu} \mathrm{L}^{-1} \\
\text { as Cu-NPs }\end{array}$ & $\begin{array}{c}100 \mu \mathrm{g} \mathrm{Cu} \mathrm{L}^{-1} \\
\text { as CuSO }\end{array}$ & $\begin{array}{c}100 \mu \mathrm{g} \mathrm{Cu} \mathrm{L}^{-1} \\
\text { as Cu-NPs }\end{array}$ \\
\hline WG (\%) & $105.34 \pm 5.16^{\mathrm{a}}$ & $81.25 \pm 5.41^{\mathrm{b}}$ & $92.19 \pm 4.69^{\mathrm{b}}$ & $47.66 \pm 1.97^{\mathrm{d}}$ & $59.38 \pm 2.55^{\mathrm{c}}$ \\
SGR \% d & $2.94 \pm 0.12^{\mathrm{a}}$ & $2.40 \pm 0.17^{\mathrm{b}}$ & $2.71 \pm 0.13^{\mathrm{ab}}$ & $1.60 \pm 0.06^{\mathrm{d}}$ & $1.93 \pm 0.09^{\mathrm{c}}$ \\
FCR & $37.31 \pm 1.85^{\mathrm{d}}$ & $48.51 \pm 3.25^{\mathrm{c}}$ & $42.48 \pm 2.16^{\mathrm{cd}}$ & $82.37 \pm 3.26^{\mathrm{a}}$ & $66.16 \pm 2.87^{\mathrm{b}}$ \\
PER & $1.61 \pm 0.08^{\mathrm{a}}$ & $1.24 \pm 0.08^{\mathrm{b}}$ & $1.41 \pm 0.07^{\mathrm{ab}}$ & $0.73 \pm 0.03^{\mathrm{c}}$ & $0.91 \pm 0.04^{\mathrm{c}}$ \\
\hline
\end{tabular}

Data are means \pm S.E.M $(n=3)$. Significant differences $(P \leq 0.05)$ among treatments were indicated by different letters in each row.

TABLE 2: Effect of Cu-NPs and $\mathrm{CuSO}_{4}$ on whole-body composition (\% on wet weight basis) of juvenile Epinephelus coioides after 25-day exposure.

\begin{tabular}{lcccrc}
\hline & Control & $\begin{array}{c}20 \mu \mathrm{g} \mathrm{Cu} \mathrm{L}^{-1} \\
\mathrm{as} \mathrm{CuSO}_{4}\end{array}$ & $\begin{array}{c}20 \mu \mathrm{g} \mathrm{Cu} \mathrm{L}^{-1} \\
\text { as Cu-NPs }\end{array}$ & $\begin{array}{c}100 \mu \mathrm{g} \mathrm{Cu} \mathrm{L}^{-1} \\
\text { as CuSO }\end{array}$ & $\begin{array}{c}100 \mu \mathrm{g} \mathrm{Cu} \mathrm{L}^{-1} \\
\text { as Cu}-\mathrm{NPs}^{\mathrm{a}}\end{array}$ \\
\hline Crude protein (\%) & $16.11 \pm 0.89^{\mathrm{a}}$ & $14.74 \pm 0.28^{\mathrm{ab}}$ & $15.94 \pm 0.40^{\mathrm{a}}$ & $13.53 \pm 0.60^{\mathrm{b}}$ & $14.85 \pm 0.29^{\mathrm{ab}}$ \\
Crude lipid (\%) & $7.94 \pm 0.46^{\mathrm{a}}$ & $6.87 \pm 0.28^{\mathrm{b}}$ & $7.57 \pm 0.30^{\mathrm{ab}}$ & $5.30 \pm 0.17^{\mathrm{c}}$ & $5.83 \pm 0.20^{\mathrm{c}}$ \\
Ash (\%) & $5.03 \pm 0.11^{\mathrm{b}}$ & $5.11 \pm 0.14^{\mathrm{b}}$ & $5.08 \pm 0.10^{\mathrm{b}}$ & $5.83 \pm 0.14^{\mathrm{a}}$ & $5.73 \pm 0.17^{\mathrm{a}}$ \\
Moisture (\%) & $71.32 \pm 0.67^{\mathrm{d}}$ & $73.27 \pm 0.30^{\mathrm{bc}}$ & $72.32 \pm 0.33^{\mathrm{cd}}$ & $75.34 \pm 0.43^{\mathrm{a}}$ & $73.59 \pm 0.47^{\mathrm{b}}$ \\
\hline
\end{tabular}

Data are means \pm S.E.M $(n=3)$. Significant differences $(P \leq 0.05)$ among treatments were indicated by different letters in each row.

decreased with increasing $\mathrm{CuSO}_{4}$ or $\mathrm{Cu}-\mathrm{NPs}$ dose. For liver and stomach, the $\mathrm{CuSO}_{4}$ treatment resulted in lower protease, amylase, and lipase activities than the Cu-NPs treatment, but opposite results were recorded for intestine (Figure 1).

3.3. Whole-Body Composition. The whole-body composition was significantly affected by the treatments (Table 2). Crude protein and crude lipid decreased with an increase in $\mathrm{CuSO}_{4}$ and $\mathrm{Cu}-\mathrm{NPs}$ dose, more so in the $\mathrm{CuSO}_{4}$ than $\mathrm{Cu}-\mathrm{NPs}$ treatment. However, ash and moisture increased with an increase in $\mathrm{CuSO}_{4}$ and $\mathrm{Cu}-\mathrm{NPs}$ dose, with the highest ash and moisture at $100 \mu \mathrm{g} \mathrm{Cu} \mathrm{L}^{-1}$ as $\mathrm{CuSO}_{4}$ (Table 2).

3.4. Whole-Body Fatty Acid Composition. As can be seen from Table 3, eicosapentaenoic acid (EPA, C20: 5), docosahexaenoic acid (DHA, C22: 6), and docosapentaenoic acid (DPA, C22: 5) were the lowest at $100 \mu \mathrm{g} \mathrm{Cu} \mathrm{L}^{-1}$ as $\mathrm{CuSO}_{4}$. The total polyunsaturated fatty acids ( $\sum$ PUFA) decreased with an increase in $\mathrm{CuSO}_{4}$ and $\mathrm{Cu}-\mathrm{NPs}$ dose, and the lowest $\sum$ PUFA were found at $100 \mu \mathrm{g} \mathrm{Cu} \mathrm{L}^{-1}$ as $\mathrm{CuSO}_{4}$. However, total monounsaturated fatty acids ( $\sum$ MUFA) and total saturated fatty acids ( $\sum$ SFA) increased with an increase in $\mathrm{CuSO}_{4}$ and $\mathrm{Cu}-\mathrm{NPs}$ dose, with the highest $\sum$ MUFA and $\sum \mathrm{SFA}$ at $100 \mu \mathrm{g} \mathrm{Cu} \mathrm{L}^{-1}$ as $\mathrm{CuSO}_{4}$ (Table 3).

3.5. Histological Observations. Liver from control specimens showed the normal structure of sinusoids and vascular system. However, liver from the treatment with $100 \mu \mathrm{g} \mathrm{Cu} \mathrm{L}^{-1}$ as either $\mathrm{CuSO}_{4}$ or $\mathrm{Cu}-\mathrm{NPs}$ showed blood cell deposition in veins and dilatation of sinusoids, with the sinusoids becoming irregular in shape (Figure 2). These injuries were greater in the $\mathrm{CuSO}_{4}$ than $\mathrm{Cu}-\mathrm{NPs}$ treatment. No significant histological evidence of injury in liver and gills was observed in the treatment with $20 \mu \mathrm{g} \mathrm{Cu} \mathrm{L}^{-1}$ as $\mathrm{CuSO}_{4}$ or Cu-NPs (data not shown). In $100 \mu \mathrm{g} \mathrm{Cu} \mathrm{L}^{-1}$ as $\mathrm{CuSO}_{4}$ or $\mathrm{Cu}-\mathrm{NPs}$, the gills showed areas of hyperplasia at the base of the secondary lamellae, clubbed tips at the top of some secondary lamellae, and aneurism in gill filaments (Figure 2).

\section{Discussion}

The water quality of the aquatic environment is the main factor controlling the health of cultured as well as wild fish [36]. Pollution of the aquatic environment by metals is a serious threat to the growth and survival of aquatic organisms including fish [37, 38]. Shaw et al. [7] reported 85\% mortality of rainbow trout in $100 \mu \mathrm{g} \mathrm{Cu} \mathrm{L}{ }^{-1}$ as $\mathrm{CuSO}_{4}$ and $14 \%$ mortality in $100 \mu \mathrm{g} \mathrm{Cu} \mathrm{L}^{-1}$ as $\mathrm{Cu}$-NPs after 4 days. In our study, almost all parameters evaluated were affected by both forms of $\mathrm{Cu}$ exposure, but no mortality was observed after 25 days of exposure to $\mathrm{CuSO}_{4}$ or $\mathrm{Cu}-\mathrm{NPs}$ (up to $100 \mu \mathrm{g} \mathrm{Cu} \mathrm{L}{ }^{-1}$ ). These results may indicate differential sensitivity of different species to $\mathrm{Cu}$ toxicity, but further work is necessary to elucidate relevant relationships.

The present study is one of the first reports detailing the effects of $\mathrm{Cu}-\mathrm{NPs}$ on juvenile Epinephelus coioides compared to $\mathrm{Cu}$ added as $\mathrm{CuSO}_{4}$. Either $\mathrm{Cu}-\mathrm{NPs}$ or $\mathrm{CuSO}_{4}$ exposure decreased WG and $\mathrm{SGR}_{\mathrm{d}}$ compared to control. Chen et al. [17] reported that the reduction in growth performance was most likely due to two reasons: first, $\mathrm{Cu}$ exposure caused increased metabolic expenditure for detoxification and maintenance of homeostasis; second, higher $\mathrm{Cu}$ exposure reduced feed intake, which would in turn lead to reduced growth. In our study, the food was eaten within 5 min of presentation, with no waste in any of the treatments, suggesting the increased metabolic expenditure for detoxification and maintenance of homeostasis and/or decreased digestive capabilities were the main reasons for decreased growth performance of juvenile Epinephelus coioides rather than decreased food intake. Indeed, growth is a complex phenomenon that partly relies 


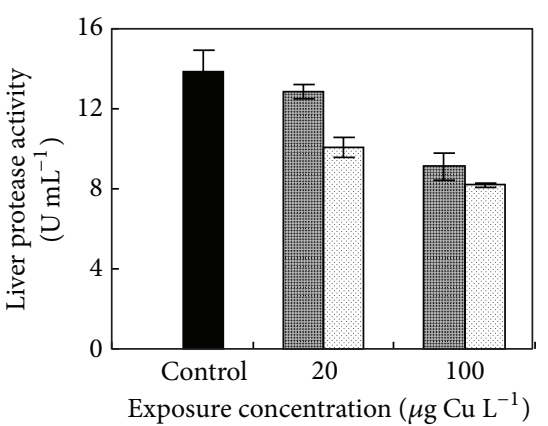

(a)

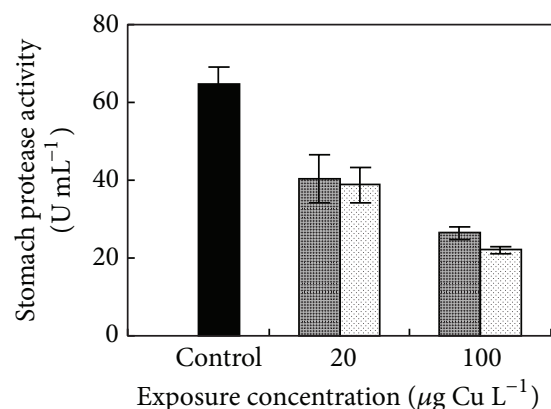

(d)

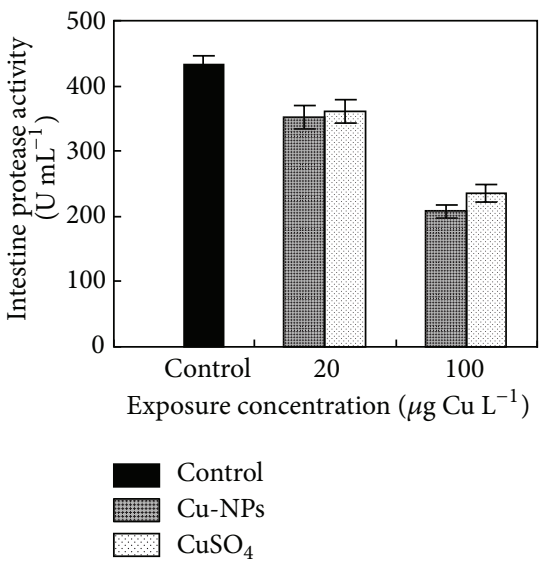

(g)

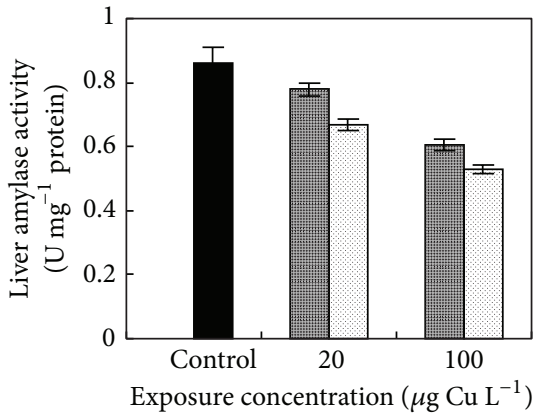

(b)

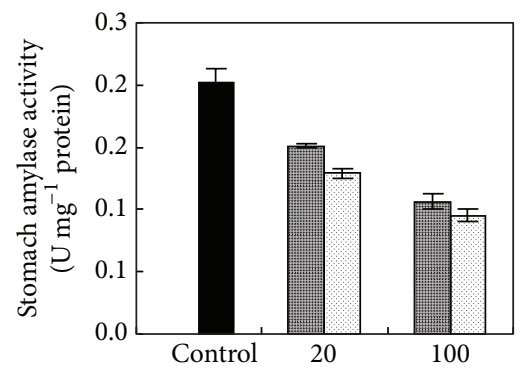

Exposure concentration $\left(\mu \mathrm{g} \mathrm{Cu} \mathrm{L}{ }^{-1}\right)$

(e)

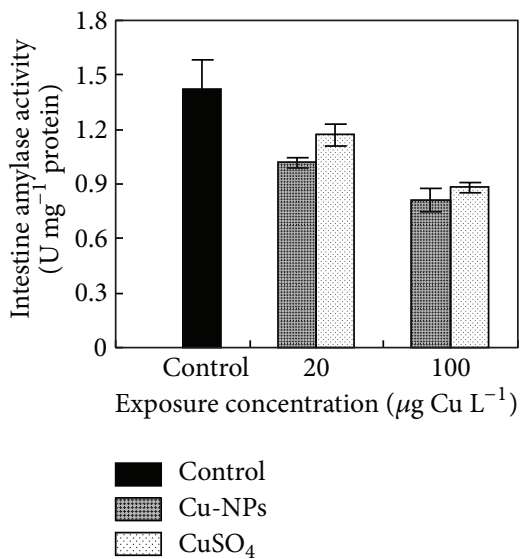

(h)

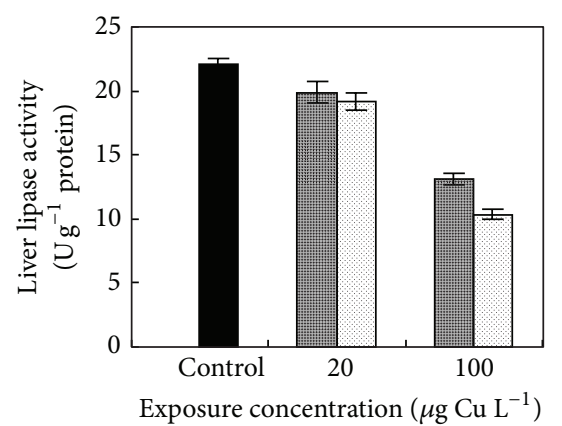

(c)

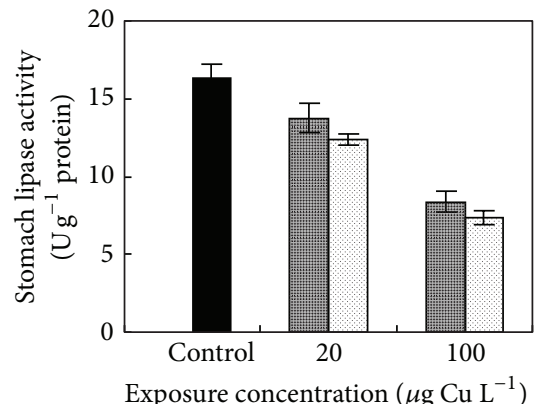

(f)

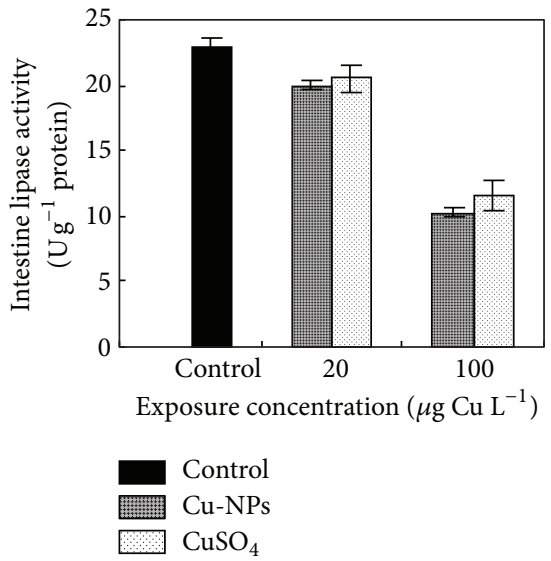

(i)

Figure 1: Effects of $\mathrm{Cu}-\mathrm{NPs}$ and $\mathrm{CuSO}_{4}$ on digestive enzyme activities (protease ((a), (d), (g)), amylase ((b), (e), (h)), and lipase ((c), (f), (i)) in liver $((\mathrm{a})-(\mathrm{c}))$, stomach $((\mathrm{d})-(\mathrm{f}))$, and intestines $((\mathrm{g})-(\mathrm{i}))$ of juvenile Epinephelus coioides after 25-day exposure.

on the digestive capabilities of an organism [39]. Sherwood et al. [40] reported that yellow perch living in lakes subjected to chronic exposure to metals (cadmium, copper and zinc) exhibited greater total energetic costs and lower SGR than fish in reference lakes, despite similar food consumption rates. In the study presented here, diminished growth with either form of $\mathrm{Cu}$ exposure was associated with increased FCR and decreased PER. Such results may be disappointing for commercial fish farming due to economic reasons because both $\mathrm{Cu}-\mathrm{NPs}$ and $\mathrm{CuSO}_{4}$ should be strictly monitored in the aquatic environment in actual fish production. This study also found that the $\mathrm{CuSO}_{4}$ treatment resulted in a lower growth performance than the $\mathrm{Cu}-\mathrm{NPs}$ treatment; in addition, the highest FCR and the lowest PER were obtained in the $\mathrm{CuSO}_{4}$ treatment, indicating that soluble $\mathrm{Cu}$ was more harmful than $\mathrm{Cu}-\mathrm{NPs}$ to fish growth and food utilization.

During ontogenetic development, marine fish undergo many changes in the structure and function of their digestive system [41, 42]. Digestive enzyme activity (e.g., protease, amylase, and lipase) can be used as an indicator of potential feed utilization and growth differences $[39,43]$ and to some extent may serve as an indicator of the digestive capacity in relation to the type of feed offered and the properties of aquaculture environments $[42,44]$. In our study, the activities of protease, amylase, and lipase found in liver, stomach, and intestine decreased with increasing $\mathrm{CuSO}_{4}$ or $\mathrm{Cu}$-NPs dose, suggesting that either $\mathrm{Cu}-\mathrm{NPs}$ or $\mathrm{CuSO}_{4}$ exposure decreased digestive capability of juvenile Epinephelus coioides. 
TABLE 3: Effects of Cu-NPs and $\mathrm{CuSO}_{4}$ on whole-body fatty acid composition of juvenile Epinephelus coioides after 25 days exposure.

\begin{tabular}{|c|c|c|c|c|c|}
\hline \multirow[b]{2}{*}{ Fatty acid } & \multicolumn{5}{|c|}{ Treatments } \\
\hline & Control & $\begin{array}{c}20 \mu \mathrm{g} \mathrm{Cu} \mathrm{L}^{-1} \\
\text { as } \mathrm{CuSO}_{4}\end{array}$ & $\begin{array}{c}20 \mu \mathrm{g} \mathrm{Cu} \mathrm{L}^{-1} \\
\text { as Cu-NPs } \\
\% \text { total fatty acids }\end{array}$ & $\begin{array}{c}100 \mu \mathrm{g} \mathrm{Cu} \mathrm{L}^{-1} \\
\quad \text { as } \mathrm{CuSO}_{4}\end{array}$ & $\begin{array}{c}100 \mu \mathrm{g} \mathrm{Cu} \mathrm{L}^{-1} \\
\text { as Cu-NPs }\end{array}$ \\
\hline C14:0 & $1.39 \pm 0.06^{\mathrm{c}}$ & $1.41 \pm 0.03^{c}$ & $1.33 \pm 0.07^{\mathrm{c}}$ & $2.43 \pm 0.07^{\mathrm{a}}$ & $1.87 \pm 0.10^{b}$ \\
\hline C15:0 & $0.25 \pm 0.03^{b c}$ & $0.24 \pm 0.02^{c}$ & $0.36 \pm 0.05^{\mathrm{ab}}$ & $0.39 \pm 0.06^{\mathrm{a}}$ & $0.28 \pm 0.04^{\mathrm{abc}}$ \\
\hline $\mathrm{C} 16: 0$ & $18.13 \pm 1.31^{\mathrm{a}}$ & $18.28 \pm 1.33^{\mathrm{a}}$ & $17.69 \pm 1.56^{\mathrm{a}}$ & $20.35 \pm 1.44^{\mathrm{a}}$ & $18.26 \pm 1.20^{\mathrm{a}}$ \\
\hline C16:1 & $2.51 \pm 0.07^{\mathrm{e}}$ & $2.72 \pm 0.04^{\mathrm{d}}$ & $2.96 \pm 0.07^{\mathrm{c}}$ & $4.04 \pm 0.09^{\mathrm{a}}$ & $3.42 \pm 0.10^{\mathrm{b}}$ \\
\hline $\mathrm{C} 17: 0$ & $0.36 \pm 0.08^{\mathrm{a}}$ & $0.38 \pm 0.05^{\mathrm{a}}$ & $0.37 \pm 0.09^{\mathrm{a}}$ & $0.49 \pm 0.11^{\mathrm{a}}$ & $0.36 \pm 0.16^{\mathrm{a}}$ \\
\hline C18:0 & $8.22 \pm 1.22^{\mathrm{a}}$ & $8.52 \pm 1.75^{\mathrm{a}}$ & $8.57 \pm 1.42^{\mathrm{a}}$ & $8.04 \pm 1.11^{\mathrm{a}}$ & $8.34 \pm 1.38^{\mathrm{a}}$ \\
\hline C18:1 & $17.16 \pm 0.06^{\mathrm{c}}$ & $17.25 \pm 0.05^{\mathrm{c}}$ & $17.09 \pm 0.04^{c}$ & $19.03 \pm 0.07^{\mathrm{a}}$ & $17.79 \pm 0.11^{\mathrm{b}}$ \\
\hline C18:2 & $21.77 \pm 2.03^{\mathrm{a}}$ & $21.03 \pm 2.08^{\mathrm{a}}$ & $20.45 \pm 2.01^{\mathrm{a}}$ & $21.17 \pm 2.33^{\mathrm{a}}$ & $21.99 \pm 1.99^{\mathrm{a}}$ \\
\hline $\mathrm{C} 18: 3$ & $1.72 \pm 0.04^{\mathrm{b}}$ & $1.50 \pm 0.06^{c}$ & $1.72 \pm 0.08^{\mathrm{b}}$ & $1.91 \pm 0.09^{\mathrm{b}}$ & $2.13 \pm 0.10^{\mathrm{a}}$ \\
\hline C20:0 & $0.30 \pm 0.03^{\mathrm{ab}}$ & $0.37 \pm 0.03^{\mathrm{a}}$ & $0.33 \pm 0.02^{\mathrm{ab}}$ & $0.35 \pm 0.01^{\mathrm{ab}}$ & $0.29 \pm 0.04^{\mathrm{b}}$ \\
\hline C20:1 & $0.62 \pm 0.07^{\mathrm{a}}$ & $0.68 \pm 0.06^{\mathrm{a}}$ & $0.72 \pm 0.08^{\mathrm{a}}$ & $0.73 \pm 0.04^{\mathrm{a}}$ & $0.71 \pm 0.05^{\mathrm{a}}$ \\
\hline C20:5 EPA & $5.48 \pm 0.11^{\mathrm{b}}$ & $5.97 \pm 0.18^{\mathrm{a}}$ & $6.25 \pm 0.14^{\mathrm{a}}$ & $4.00 \pm 0.17^{\mathrm{c}}$ & $5.31 \pm 0.12^{\mathrm{b}}$ \\
\hline $\mathrm{C} 22: 0$ & $0.10 \pm 0.01^{c}$ & $0.14 \pm 0.09^{c}$ & $0.28 \pm 0.02^{\mathrm{b}}$ & $0.47 \pm 0.05^{\mathrm{a}}$ & $0.13 \pm 0.01^{\mathrm{c}}$ \\
\hline C22:5DPA & $1.65 \pm 0.06^{\mathrm{ab}}$ & $1.51 \pm 0.06^{\mathrm{b}}$ & $1.82 \pm 0.09^{\mathrm{a}}$ & $1.20 \pm 0.11^{\mathrm{c}}$ & $1.59 \pm 0.12^{\mathrm{ab}}$ \\
\hline C22:6DHA & $17.91 \pm 1.02^{\mathrm{a}}$ & $17.27 \pm 1.22^{\mathrm{ab}}$ & $17.19 \pm 1.31^{\mathrm{ab}}$ & $12.71 \pm 1.23^{\mathrm{c}}$ & $14.54 \pm 1.11^{\mathrm{bc}}$ \\
\hline$\sum \mathrm{SFA}$ & $28.75 \pm 0.39^{\mathrm{b}}$ & $29.34 \pm 0.47^{\mathrm{b}}$ & $28.91 \pm 0.46^{\mathrm{b}}$ & $32.53 \pm 0.41^{\mathrm{a}}$ & $29.53 \pm 0.42^{b}$ \\
\hline$\sum$ MUFA & $20.29 \pm 0.07^{\mathrm{d}}$ & $20.65 \pm 0.05^{c}$ & $20.76 \pm 0.06^{c}$ & $23.80 \pm 0.07^{\mathrm{a}}$ & $21.92 \pm 0.09^{\mathrm{b}}$ \\
\hline$\sum$ PUFA & $48.52 \pm 0.65^{\mathrm{a}}$ & $47.29 \pm 0.72^{\mathrm{ab}}$ & $47.42 \pm 0.73^{\mathrm{ab}}$ & $41.00 \pm 0.79^{c}$ & $45.56 \pm 0.69^{b}$ \\
\hline Others & $2.44 \pm 0.64^{\mathrm{a}}$ & $2.72 \pm 0.72^{\mathrm{a}}$ & $2.91 \pm 0.72^{\mathrm{a}}$ & $2.67 \pm 0.73^{\mathrm{a}}$ & $2.88 \pm 0.78^{\mathrm{a}}$ \\
\hline
\end{tabular}

Data are means \pm S.E.M $(n=3)$. Significant differences $(P \leq 0.05)$ among treatments were indicated by different letters in each row. EPA: eicosapentaenoic acid; DPA: dichloropropanoic acid; DHA: docosahexaenoic acid; $\sum$ SFA: total saturated fatty acids; $\sum$ MUFA: total monounsaturated fatty acids; $\sum$ PUFA: total polyunsaturated fatty acids.

Several hypotheses can explain the negative effect of contaminants on digestive enzyme activities: (i) contaminants can act directly on digestive enzymes activities and/or their synthesis [16]; (ii) contaminants can act negatively on the fish behavior, for example, by decreasing the feeding activity, with indirect consequences on digestive enzymes [43, 45]; (iii) the quantity and the quality of available food may also be impacted by the pollution level, leading to a variation in the activities of digestive enzymes [42]. In this experiment, either $\mathrm{Cu}-\mathrm{NPs}$ or $\mathrm{CuSO}_{4}$ exposure had no appreciable effect on feeding activity (as judged from the food being eaten within $5 \mathrm{~min}$ of presentation regardless of the treatment). Thus, $\mathrm{Cu}$ exposure could act directly on digestive enzyme activities and/or synthesis, which contributed to the lower growth performance.

In liver and stomach, the $\mathrm{CuSO}_{4}$ treatment resulted in lower digestive enzyme activities than the $\mathrm{Cu}-\mathrm{NPs}$ treatment, but the opposite results were recorded for intestine. This result is in accordance with our previous report [6] on $\mathrm{Cu}$ accumulation, regarding a negative relationship between $\mathrm{Cu}$ accumulation (or $\mathrm{Cu}$ exposure concentration) and digestive enzyme activities under either form of $\mathrm{Cu}$ exposure. In intestine, the $\mathrm{Cu}-\mathrm{NPs}$ treatment was associated with higher $\mathrm{Cu}$ concentration compared with the $\mathrm{CuSO}_{4}$ treatment [6]; hence, digestive enzyme activities were lower in the $\mathrm{Cu}-\mathrm{NPs}$ than in $\mathrm{CuSO}_{4}$ treatment.
Shearer [46] reported that concentrations of crude protein and ash varied during the life cycle and were dependent on the fish size. Abdel-Tawwab et al. [47] assumed that changes in body composition such as crude protein and crude lipid contents could be linked to changes in their synthesis, deposition rate in muscle, and/or differential growth rates. Chen et al. [17] and Shearer [46] reported that deposition of lipids was influenced by several factors, but there was a general trend for percentage body lipids to decrease with decreasing fish size, and any decrease in the percentage of lipids was usually accompanied by an increase in percentage of body water. The results of the present study are in general accord with this. It is likely that the proteins and lipids in fish can be used as energy source for detoxification and the maintenance of homeostasis during metal exposure [48, 49]. In the present study, crude proteins and crude lipids decreased with an increase in $\mathrm{CuSO}_{4}$ and $\mathrm{Cu}$-NPs dose, more so in the $\mathrm{CuSO}_{4}$ than $\mathrm{Cu}$-NPs treatment, indicating that $\mathrm{Cu}$ ions were more harmful to energy stores (such as crude proteins and crude lipids) and weight gain of Epinephelus coioides than Cu-NPs. However, Chen et al. [17] found that waterborne cadmium exposure $\left(0.49\right.$ and $\left.0.95 \mathrm{mg} \mathrm{L}^{-1}\right)$ increased lipid content of yellow catfish. In conclusion, lipid metabolism under metal exposure revealed a complex regulatory mechanism and diverse biological functions of 


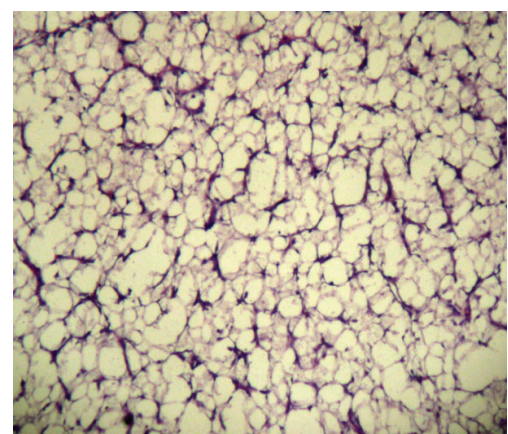

(a)

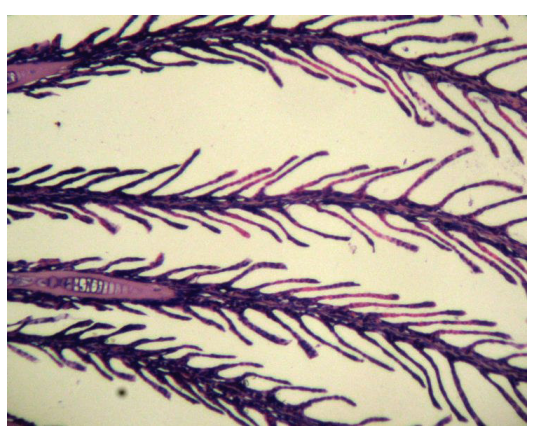

(d)

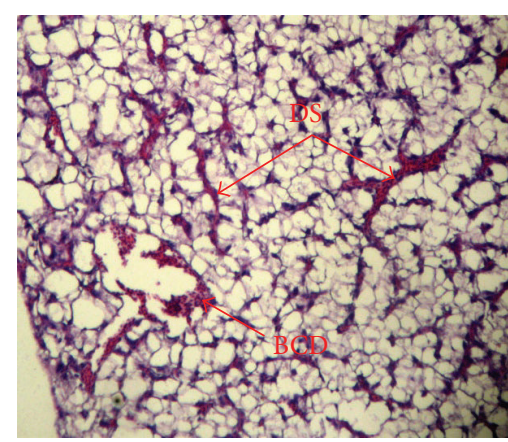

(b)

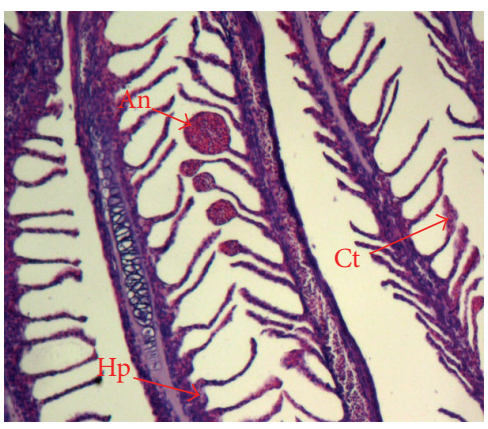

(e)

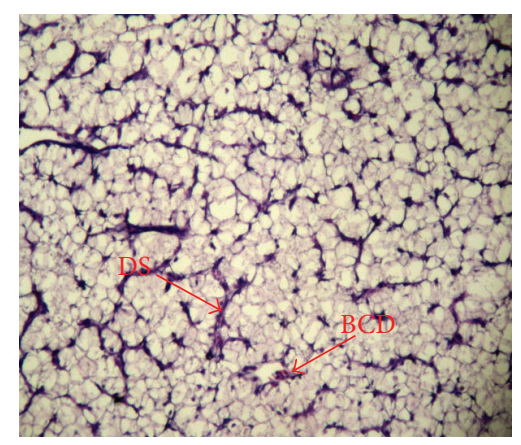

(c)

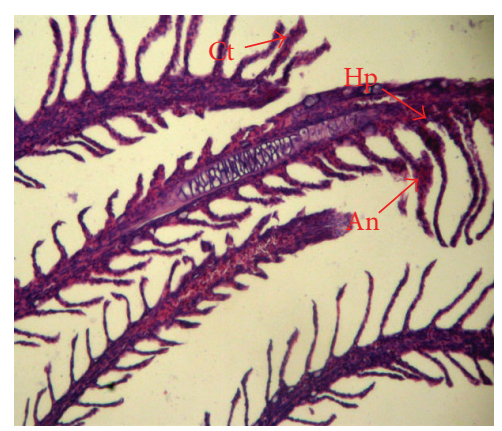

(f)

Figure 2: Effects of Cu-NPs and $\mathrm{CuSO}_{4}$ on liver and gills morphology of juvenile Epinephelus coioides after 25-day exposure. (a) Liver from control, (b) liver from $100 \mu \mathrm{g} \mathrm{Cu} \mathrm{L}^{-1}$ as $\mathrm{CuSO}_{4}$, (c) liver from $100 \mu \mathrm{g} \mathrm{Cu} \mathrm{L}{ }^{-1}$ as Cu-NPs, (d) gills from control, (e) gills from $100 \mu \mathrm{g} \mathrm{Cu} \mathrm{L}{ }^{-1}$ as $\mathrm{CuSO}_{4}$, and (f) gills from $100 \mu \mathrm{g} \mathrm{Cu} \mathrm{L}{ }^{-1}$ as Cu-NPs. In liver, all treatments showed injuries that include blood cell deposition in veins (BCD) and dilatation of sinusoids (DS). In gills, all treatments showed injuries that include hyperplasia (Hp), aneurism (An), and clubbed tips (Ct). Sections were $7-\mu \mathrm{m}$ thick and stained with haematoxylin and eosin $(\mathrm{H} \& \mathrm{E}, \times 100)$.

different species and organs $[17,50]$, so further study is needed.

Metals are highly hazardous xenobiotics. However, optimization of the lipid and fatty acid metabolism may promote the adaptation of an organism to the adverse environmental conditions (cf. Fokina et al. [24]). Sáez et al. [23] reported that the fatty acid composition in the whole body of Gambusia holbrooki was obviously changed after the treatment with 0.1 , 0.17 , or $0.25 \mathrm{mg} \mathrm{Cu} \mathrm{L}^{-1}$ as $\mathrm{CuSO}_{4}$ compared to control. Fokina et al. [24] found that saturated fatty acids (SFA) and monounsaturated fatty acids (MUFA) in gills of mussels decreased significantly after $24 \mathrm{~h}$ exposure to 5,50 , or $250 \mu \mathrm{g}$ soluble $\mathrm{Cu} \mathrm{L}^{-1}$, but polyunsaturated fatty acids (PUFA) content in gills increased (primarily a rise in EPA, DHA, and AA acids). Borlongan [51] reported that EPA and DHA were the essential fatty acids for fish, but marine fish may have limited ability to synthesize them. Furthermore, DHA and EPA were closely related to the physiological functions of fish, including the antioxidant, immune, and anti-inflammatory responses, as well as protecting the retina and improving vision $[12,52]$. In our study, EPA, DHA, and DPA were significantly influenced by the $\mathrm{CuSO}_{4}$ or $\mathrm{Cu}-\mathrm{NPs}$ treatment, with the lowest content at $100 \mu \mathrm{g} \mathrm{Cu} \mathrm{L}^{-1}$ as $\mathrm{CuSO}_{4}$, indicating that the physiological functions of juvenile Epinephelus coioides might be impaired by either form of $\mathrm{Cu}$ treatment, even though more so by $\mathrm{Cu}$ ions than $\mathrm{Cu}-\mathrm{NPs}$. With an increase in $\mathrm{CuSO}_{4}$ or $\mathrm{Cu}-\mathrm{NPs}$ dose, $\sum$ PUFA decreased, but $\sum$ MUFA and $\sum$ SFA increased compared to control. These results may be related to the oxidative stress of juvenile Epinephelus coioides under either form of $\mathrm{Cu}$ exposure [6].

Metals may alter the structure of cell membranes by stimulating lipid peroxidation [53] caused by free oxygen radicals (superoxide $\left(\mathrm{O}_{2}{ }^{\circ}\right)$ transforming into higher activity oxyradicals, such as hydroxyl $\left(\mathrm{OH}^{\circ}\right)$ and singlet oxygen $\left.\left({ }^{1} \mathrm{O}_{2}\right)\right)$. PUFA may be attacked by these oxyradicals, which may stimulate production of lipid radicals and finally aldehydes (such as MDA), ketones, carboxylic acids, and hydrocarbons [24, 54]. In the study presented here, $\sum$ PUFA content decreased and the concentration of MDA increased in juvenile Epinephelus coioides (also in our previous study, Wang et al. [6]) compared to control, in accordance to Fokina et al. [24] and D. E. Vance and J. E. Vance [55]. Our study also found the lowest $\sum$ PUFA; in contrast, the highest $\sum$ MUFA and $\sum$ SFA content were found in the treatment with $\mathrm{CuSO}_{4}\left(100 \mu \mathrm{g} \mathrm{Cu} \mathrm{L}^{-1}\right)$, indicating that fatty acid composition of juvenile Epinephelus coioides was affected more strongly by $\mathrm{Cu}$ ions than $\mathrm{Cu}$ $\mathrm{NPs}$, and $\mathrm{Cu}$ ions were more harmful to the cell membranes than $\mathrm{Cu}$-NPs. Therefore, the degree of $\mathrm{Cu}$ toxicity to cells was strongly related to the forms of $\mathrm{Cu}$ in the marine environment.

Histological alterations observed in liver and gills were indicative of the fish physiological status, revealing the 
mechanisms of $\mathrm{Cu}$ exposure [56]. Liver and gills were the top two organs for $\mathrm{Cu}$-NPs accumulation in juvenile Epinephelus coioides [6]. In the present study, no significant histological evidence of injury was observed in liver and gills in the treatment with $20 \mu \mathrm{g} \mathrm{Cu} \mathrm{L}^{-1}$ as $\mathrm{CuSO}_{4}$ or $\mathrm{Cu}-\mathrm{NPs}$; nevertheless, marine environments with $20 \mu \mathrm{g} \mathrm{Cu} \mathrm{L}{ }^{-1}$ pose a risk of $\mathrm{Cu}$ accumulation in juvenile Epinephelus coioides [6].

The liver is a central compartment of $\mathrm{Cu}$ metabolism in fish [2], and it has been used as a reference for analysis of tissue damage caused by environmental pollutants $[57,58]$. In the present study, liver from fish exposed to either $\mathrm{CuSO}_{4}$ or $\mathrm{Cu}$-NPs $\left(100 \mu \mathrm{g} \mathrm{Cu} \mathrm{L}^{-1}\right)$ had blood deposition in veins and dilatation of sinusoids. In other studies, dilatation of sinusoids was one of the most evident signs of liver damage in fish exposed to $\mathrm{Cu}[8,10]$. Al-Bairuty et al. [2] found that $\mathrm{CuSO}_{4}\left(100 \mu \mathrm{g} \mathrm{Cu} \mathrm{L}^{-1}\right)$ induced some cellular necrosis and changes in the sinusoid space in liver of rainbow trout; exposure to $\mathrm{Cu}-\mathrm{NPs}\left(100 \mu \mathrm{g} \mathrm{Cu} \mathrm{L}{ }^{-1}\right)$ produced the same type of pathology but affected a greater proportion of liver area and sinusoid space than $\mathrm{CuSO}_{4}$. In contrast, in the study presented here, the dilatation of liver sinusoids was greater in the fish treated with $100 \mu \mathrm{g} \mathrm{Cu} \mathrm{L}{ }^{-1}$ as $\mathrm{CuSO}_{4}$ than $\mathrm{Cu}$ NPs. The difference between the two studies could be due to different fish species and different duration of exposure; it should also be kept in mind that differential susceptibility to $\mathrm{Cu}$ could exist between freshwater and seawater fish.

Gills are an important organ for both osmoregulation and respiratory gas exchange, and they were the primary target for toxicity of Cu-NPs [59]. In the present study, gills had areas of hyperplasia at the base of the secondary lamellae, clubbed tips at the top of some secondary lamellae, and aneurism in gill filaments at $100 \mu \mathrm{g} \mathrm{Cu} \mathrm{L}^{-1}$ as $\mathrm{CuSO}_{4}$ or $\mathrm{Cu}-\mathrm{NPs}$. These results were similar with the data recorded by Al-Bairuty et al. [2] and Griffitt et al. [59]. Gomes et al. [3] and Griffitt et al. [59] reported that hyperplasia at the base of the secondary lamellae would increase the diffusion distance for gas exchange, with even a small increase having profound effects on the efficiency of oxygen transfer across gills. Gill injuries from metal exposure were associated with a decrease in arterial oxygen tension, which might be recoverable depending on the extent of the injury (e.g., Zn, Lappivaara et al., [60]). Decreases in arterial oxygen tension in fish exposed to NPs have also been reported [61]. It, therefore, seems probable that the gill injury reported here would cause some hypoxia. Further research on the exercise performance and swimming behaviour of fish exposed to $\mathrm{Cu}-$ NPs is required to determine the functional significance of observed gill pathology.

\section{Conclusions}

The present study confirmed that either $\mathrm{Cu}-\mathrm{NPs}$ or $\mathrm{CuSO}_{4}$ exposure had obvious toxicity to juvenile Epinephelus coioides. Either form of $\mathrm{Cu}$ exposure inhibited digestive enzyme activities, which contributed to the diminished growth performance. The crude proteins and crude lipids in fish might be used as energy source for detoxification and the maintenance of homeostasis during $\mathrm{Cu}-\mathrm{NPs}$ or $\mathrm{CuSO}_{4}$ exposure; thus fish qualities (whole-body composition and fatty acid composition) were obviously affected after either form of $\mathrm{Cu}$ exposure. A similar type of pathology was caused by $\mathrm{Cu}-\mathrm{NPs}$ or $\mathrm{Cu}$ metal salts, but greater injuries were found in liver of fish exposed to $\mathrm{CuSO}_{4}$ than $\mathrm{Cu}$-NPs. The studied parameters in fish treated by metals could be used as biomarkers, reflecting the adverse effects of marine environment on fish. Finally, considering the importance of this species for fish culture, a further exploration from genomic, transcriptomic, proteomic, and metabolomics should be provided to elaborate for the diminished growth performance after $\mathrm{Cu}$ exposure.

\section{Conflict of Interests}

The authors declare that there is no conflict of interests regarding the publication of this paper.

\section{Acknowledgments}

The authors are grateful for the financial support of the National Key Projects of Scientific and Technical Support Programs funded by the Ministry of Science and Technology of China (nos. 2011BAD13B09).

\section{References}

[1] F. Li, Z. Liang, X. Zheng, W. Zhao, M. Wu, and Z. Wang, "Toxicity of nano- $\mathrm{TiO}_{2}$ on algae and the site of reactive oxygen species production," Aquatic Toxicology, vol. 158, pp. 1-13, 2015.

[2] G. A. Al-Bairuty, B. J. Shaw, R. D. Handy, and T. B. Henry, "Histopathological effects of waterborne copper nanoparticles and copper sulphate on the organs of rainbow trout (Oncorhynchus mykiss)," Aquatic Toxicology, vol. 126, pp. 104115, 2013.

[3] T. Gomes, J. P. Pinheiro, I. Cancio, C. G. Pereira, C. Cardoso, and M. J. Bebianno, "Effects of copper nanoparticles exposure in the mussel Mytilus galloprovincialis," Environmental Science \& Technology, vol. 45, no. 21, pp. 9356-9362, 2011.

[4] A. D. Maynard, R. J. Aitken, T. Butz et al., "Safe handling of nanotechnology," Nature, vol. 444, no. 7117, pp. 267-269, 2006.

[5] J. Zhao, Z. Wang, X. Liu, X. Xie, K. Zhang, and B. Xing, "Distribution of $\mathrm{CuO}$ nanoparticles in juvenile carp (Cyprinus carpio) and their potential toxicity," Journal of Hazardous Materials, vol. 197, pp. 304-310, 2011.

[6] T. Wang, X. Long, Y. Cheng, Z. Liu, and S. Yan, "The potential toxicity of copper nanoparticles and copper sulphate on juvenile Epinephelus coioides," Aquatic Toxicology, vol. 152, pp. 96-104, 2014.

[7] B. J. Shaw, G. Al-Bairuty, and R. D. Handy, "Effects of waterborne copper nanoparticles and copper sulphate on rainbow trout, (Oncorhynchus mykiss): physiology and accumulation," Aquatic Toxicology, vol. 116-117, pp. 90-101, 2012.

[8] B. J. Shaw and R. D. Handy, "Physiological effects of nanoparticles on fish: a comparison of nanometals versus metal ions," Environment International, vol. 37, no. 6, pp. 1083-1097, 2011.

[9] Y. Cong, G. T. Banta, H. Selck, D. Berhanu, E. Valsami-Jones, and V. E. Forbes, "Toxicity and bioaccumulation of sedimentassociated silver nanoparticles in the estuarine polychaete, 
Nereis (Hediste) diversicolor," Aquatic Toxicology, vol. 156, pp. 106-115, 2014.

[10] J. M. Arellano, V. Storch, and C. Sarasquete, "Histological changes and copper accumulation in liver and gills of the senegales sole, Solea senegalensis," Ecotoxicology and Environmental Safety, vol. 44, no. 1, pp. 62-72, 1999.

[11] M. W. Beaumont, E. W. Taylor, and P. J. Butler, "The resting membrane potential of white muscle from brown trout (Salmo trutta) exposed to copper in soft, acidic water," The Journal of Experimental Biology, vol. 203, no. 14, pp. 2229-2236, 2000.

[12] T. Wang, Y. Cheng, Z. Liu, S. Yan, and X. Long, "Effects of light intensity on growth, immune response, plasma cortisol and fatty acid composition of juvenile Epinephelus coioides reared in artificial seawater," Aquaculture, vol. 414-415, pp. 135-139, 2013.

[13] L. Burridge, J. S. Weis, F. Cabello, J. Pizarro, and K. Bostick, "Chemical use in salmon aquaculture: a review of current practices and possible environmental effects," Aquaculture, vol. 306, no. $1-4$, pp. 7-23, 2010.

[14] W. Wang, K. Mai, W. Zhang et al., "Effects of dietary copper on survival, growth and immune response of juvenile abalone, Haliotis discus hannai Ino," Aquaculture, vol. 297, no. 1-4, pp. 122-127, 2009.

[15] Y. H. Lin, Y. Y. Shie, and S. Y. Shiau, "Dietary copper requirements of juvenile grouper, Epinephelus malabaricus," Aquaculture, vol. 274, no. 1, pp. 161-165, 2008.

[16] O. Dedourge-Geffard, F. Palais, S. Biagianti-Risbourg, and A. Geffard, "Effects of metals on feeding rate and digestive enzymes in Gammarus fossarum: an in situ experiment," Chemosphere, vol. 77, no. 11, pp. 1569-1576, 2009.

[17] Q.-L. Chen, Z. Luo, Y.-X. Pan et al., "Differential induction of enzymes and genes involved in lipid metabolism in liver and visceral adipose tissue of juvenile yellow catfish Pelteobagrus fulvidraco exposed to copper," Aquatic Toxicology, vol. 136-137, pp. 72-78, 2013.

[18] D. Lapointe, F. Pierron, and P. Couture, "Individual and combined effects of heat stress and aqueous or dietary copper exposure in fathead minnows (Pimephales promelas)," Aquatic Toxicology, vol. 104, no. 1-2, pp. 80-85, 2011.

[19] R. D. Handy, "Chronic effects of copper exposure versus endocrine toxicity: two sides of the same toxicological process?" Comparative Biochemistry and Physiology Part A: Molecular and Integrative Physiology, vol. 135, no. 1, pp. 25-38, 2003.

[20] M. Mela, I. C. Guiloski, H. B. Doria et al., "Risks of waterborne copper exposure to a cultivated freshwater Neotropical catfish (Rhamdia quelen)," Ecotoxicology and Environmental Safety, vol. 88, pp. 108-116, 2013.

[21] D. J. H. Phillips, Quantitative Aquatic Biological Indicators, Applied Science Publishers, London, UK, 1980.

[22] G. R. Scott and K. A. Sloman, "The effects of environmental pollutants on complex fish behaviour: integrating behavioural and physiological indicators of toxicity," Aquatic Toxicology, vol. 68, no. 4, pp. 369-392, 2004.

[23] M. I. Sáez, S. García-Mesa, J. J. Casas et al., "Effect of sublethal concentrations of waterborne copper on lipid peroxidation and enzymatic antioxidant response in Gambusia holbrooki," Environmental Toxicology and Pharmacology, vol. 36, no. 1, pp. 125-134, 2013.

[24] N. N. Fokina, T. R. Ruokolainen, N. N. Nemova, and I. N. Bakhmet, "Changes of blue mussels Mytilus edulis L. lipid composition under cadmium and copper toxic effect," Biological Trace Element Research, vol. 154, no. 2, pp. 217-225, 2013.
[25] US-EPA, "Aquatic life ambient freshwater quality criteriacopper (CAS Registry Number 7440-50-8)," U.S. Environmental Protection Agency Office of Water, Office of Science and Technology, Washington, DC, USA, 2007.

[26] T. Sovová, D. Boyle, K. A. Sloman, C. V. Pérez, and R. D. Handy, "Impaired behavioural response to alarm substance in rainbow trout exposed to copper nanoparticles," Aquatic Toxicology, vol. 152, pp. 195-204, 2014.

[27] M. M. Bradford, "A rapid and sensitive method for the quantitation of microgram quantities of protein utilizing the principle of protein dye binding," Analytical Biochemistry, vol. 72, no. 1-2, pp. 248-254, 1976.

[28] D. Gui, W. Liu, X. Shao, and W. Xu, "Effects of different dietary levels of cottonseed meal protein hydrolysate on growth, digestibility, body composition and serum biochemical indices in crucian carp (Carassius auratus gibelio)," Animal Feed Science and Technology, vol. 156, no. 3-4, pp. 112-120, 2010.

[29] L. Rongzhu, W. Suhua, X. Guangwei et al., "Effects of acrylonitrile on antioxidant status of different brain regions in rats," Neurochemistry International, vol. 55, no. 7, pp. 552-557, 2009.

[30] AOAC, Official Methods of Analysis of Official Analytical Chemists International, Association of Official Analytical Chemists, Arlington, Va, USA, 16th edition, 1995.

[31] M. Dubois, K. A. Gilles, J. K. Hamilton, P. A. Rebers, and F. Smith, "Colorimetric method for determination of sugars and related substances," Analytical Chemistry, vol. 28, no. 3, pp. 350356, 1956.

[32] M. Yoshioka, T. Yago, Y. Yoshie-Stark, H. Arakawa, and T. Morinaga, "Effect of high frequency of intermittent light on the growth and fatty acid profile of Isochrysis galbana," Aquaculture, vol. 338-341, pp. 111-117, 2012.

[33] G. L. Humason, Animal Tissue Techniques, W.H. Freeman, New York, NY, USA, 1979.

[34] A. K. Biswas, M. Seoka, Y. Inoue, K. Takii, and H. Kumai, "Photoperiod influences the growth, food intake, feed efficiency and digestibility of red sea bream (Pagrus major)," Aquaculture, vol. 250, no. 3-4, pp. 666-673, 2005.

[35] S. O. Handeland, A. K. Imsland, and S. O. Stefansson, "The effect of temperature and fish size on growth, feed intake, food conversion efficiency and stomach evacuation rate of Atlantic salmon post-smolts," Aquaculture, vol. 283, no. 1-4, pp. 36-42, 2008.

[36] T. T. N. Yen Nhi, N. A. S. Mohd Shazili, and F. ShaharomHarrison, "Use of cestodes as indicator of heavy-metal pollution," Experimental Parasitology, vol. 133, no. 1, pp. 75-79, 2013.

[37] M. Samir and M. Ibrahim, "Assessment of heavy metals pollution in water and sediments and their effect on Oreochromis niloticus in the northern Delta Lakes, Egypt," in Proceedings of the 8th International Symposium on Tilapia in Aquaculture, pp. 475-490, 2008.

[38] E. A. Shubina, M. A. Nikitin, E. V. Ponomareva, D. V. Goryunov, and O. F. Gritsenko, "Comparative study of genome divergence in salmonids with various rates of genetic isolation," International Journal of Genomics, vol. 2013, Article ID 629543, 16 pages, 2013.

[39] P. Gómez-Requeni, F. Bedolla-Cázares, C. Montecchia et al., "Effects of increasing the dietary lipid levels on the growth performance, body composition and digestive enzyme activities of the teleost pejerrey (Odontesthes bonariensis)," Aquaculture, vol. 416-417, pp. 15-22, 2013.

[40] G. D. Sherwood, J. B. Rasmussen, D. J. Rowan, J. Brodeur, and A. Hontela, "Bioenergetic costs of heavy metal exposure in yellow 
perch (Perca flavescens): in situ estimates with a radiotracer $\left({ }^{137} \mathrm{Cs}\right)$ technique," Canadian Journal of Fisheries and Aquatic Sciences, vol. 57, no. 2, pp. 441-450, 2000.

[41] C. L. Cahu and J. L. Z. Infante, "Maturation of the pancreatic and intestinal digestive functions in sea bass (Dicentrarchus labrax): effect of weaning with different protein sources," Fish Physiology and Biochemistry, vol. 14, no. 6, pp. 431-437, 1995.

[42] C. Suzer, Ş. Saka, and K. Furat, "Effects of illumination on early life development and digestive enzyme activities in common pandora Pagellus erythrinus L. larvae," Aquaculture, vol. 260, no. 1-4, pp. 86-93, 2006.

[43] K. Rungruangsak-Torrissen, "Important parameters for growth study," in Proceedings of the 2nd International Symposium on Cultivation of Salmon II, p. 14, Bergen, Norway, May 2001.

[44] O. Dedourge-Geffard, L. Charron, C. Hofbauer et al., "Temporal patterns of digestive enzyme activities and feeding rate in gammarids (Gammarus fossarum) exposed to inland polluted waters," Ecotoxicology and Environmental Safety, vol. 97, pp. 139-146, 2013.

[45] L. Maltby and M. Crane, "Responses of Gammarus pulex (Amphipoda, Crustacea) to metalliferous effluents: identification of toxic components and the importance of interpopulation variation," Environmental Pollution, vol. 84, no. 1, pp. 45-52, 1994.

[46] K. D. Shearer, "Factors affecting the proximate composition of cultured fishes with emphasis on salmonids," Aquaculture, vol. 119, no. 1, pp. 63-88, 1994.

[47] M. Abdel-Tawwab, A. M. Abdel-Rahman, and N. E. M. Ismael, "Evaluation of commercial live bakers' yeast, Saccharomyces cerevisiae as a growth and immunity promoter for Fry Nile tilapia, Oreochromis niloticus (L.) challenged in situ with Aeromonas hydrophila," Aquaculture, vol. 280, no. 1-4, pp. 185189, 2008.

[48] S. Stefanni, R. Bettencourt, M. Pinheiro, G. de Moro, L. Bongiorni, and A. Pallavicini, "Transcriptome of the deep-sea black scabbardfish, Aphanopus carbo (Perciformes: Trichiuridae): tissue-specific expression patterns and candidate genes associated to depth adaptation," International Journal of Genomics, vol. 2014, Article ID 267482, 21 pages, 2014.

[49] J.-L. Zheng, Z. Luo, C.-X. Liu et al., "Differential effects of acute and chronic zinc ( $\mathrm{Zn}$ ) exposure on hepatic lipid deposition and metabolism in yellow catfish Pelteobagrus fulvidraco," Aquatic Toxicology, vol. 132-133, pp. 173-181, 2013.

[50] F. Pierron, M. Baudrimont, A. Bossy et al., "Impairment of lipid storage by cadmium in the European eel (Anguilla anguilla)," Aquatic Toxicology, vol. 81, no. 3, pp. 304-311, 2007.

[51] I. G. Borlongan, "The essential fatty acid requirement of milkfish (Chanos chanos Forsskal)," Fish Physiology and Biochemistry, vol. 9, no. 5-6, pp. 401-407, 1992.

[52] P. Hung, S. Kaku, S.-I. Yunoki et al., "Dietary effect of EPA-rich and DHA-rich fish oils on the immune function of SpragueDawley rats," Bioscience, Biotechnology and Biochemistry, vol. 63, no. 1, pp. 135-140, 1999.

[53] R. F. Fornazier, R. R. Ferreira, A. P. Vitória, S. M. G. Molina, P. J. Lea, and R. A. Azevedo, "Effects of cadmium on antioxidant enzyme activities in sugar cane," Biologia Plantarum, vol. 45, no. 1, pp. 91-97, 2002.

[54] A. Liavonchanka and I. Feussner, "Lipoxygenases: occurrence, functions and catalysis," Journal of Plant Physiology, vol. 163, no. 3, pp. 348-357, 2006.

[55] D. E. Vance and J. E. Vance, Biochemistry of Lipids, Lipoproteins and Membranes, Elsevier, 4th edition, 2002.
[56] C. Gravato, M. Teles, M. Oliveira, and M. A. Santos, "Oxidative stress, liver biotransformation and genotoxic effects induced by copper in Anguilla anguilla L. - the influence of pre-exposure to $\beta$-naphthoflavone," Chemosphere, vol. 65, no. 10, pp. 1821-1830, 2006.

[57] A. F. Amaral, N. Alvarado, I. Marigomez, R. Cunha, K. Hylland, and M. Soto, "Autometallography and metallothionein immunohistochemistry in hepatocytes of turbot (Scophthalmus maximus L.) after exposure to cadmium and depuration treatment," Biomarkers, vol. 7, no. 6, pp. 491-500, 2002.

[58] R. Cortés, M. Teles, R. Trídico, L. Acerete, and L. Tort, "Effects of cortisol administered through slow-release implants on innate immune responses in rainbow trout (Oncorhynchus mykiss)," International Journal of Genomics, vol. 2013, Article ID 619714, 7 pages, 2013.

[59] R. J. Griffitt, R. Weil, K. A. Hyndman et al., "Exposure to copper nanoparticles causes gill injury and acute lethality in zebrafish (Danio rerio)," Environmental Science and Technology, vol. 41, no. 23, pp. 8178-8186, 2007.

[60] J. Lappivaara, M. Nikinmaa, and H. Tuurala, "Arterial oxygen tension and the structure of the secondary lamellae of the gills in rainbow trout (Oncorhynchus mykiss) after acute exposure to zinc and during recovery," Aquatic Toxicology, vol. 32, no. 4, pp. 321-331, 1995.

[61] D. Boyle, G. A. Al-Bairuty, C. S. Ramsden, K. A. Sloman, T. B. Henry, and R. D. Handy, "Subtle alterations in swimming speed distributions of rainbow trout exposed to titanium dioxide nanoparticles are associated with gill rather than brain injury," Aquatic Toxicology, vol. 126, pp. 116-127, 2013. 

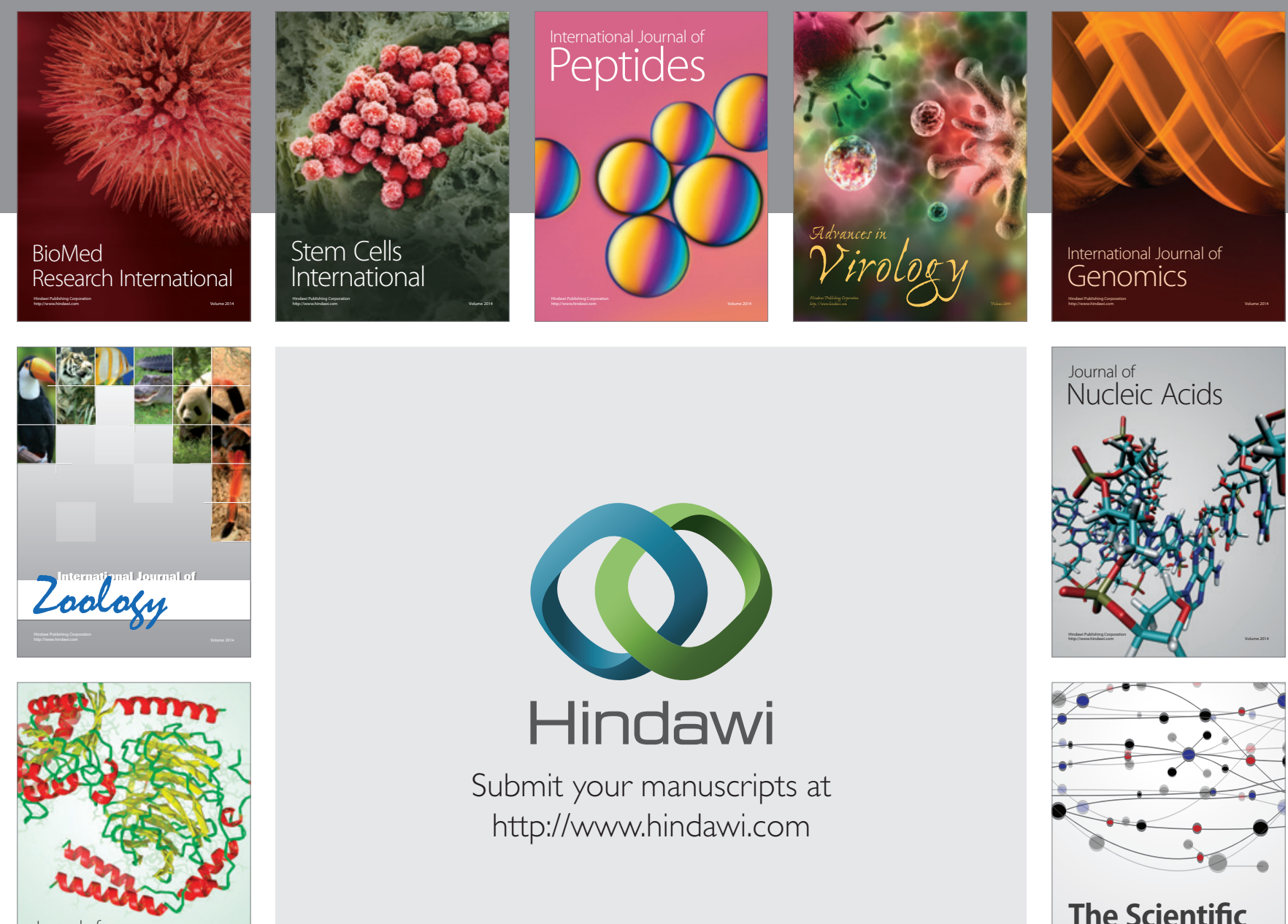

Submit your manuscripts at

http://www.hindawi.com

Journal of
Signal Transduction
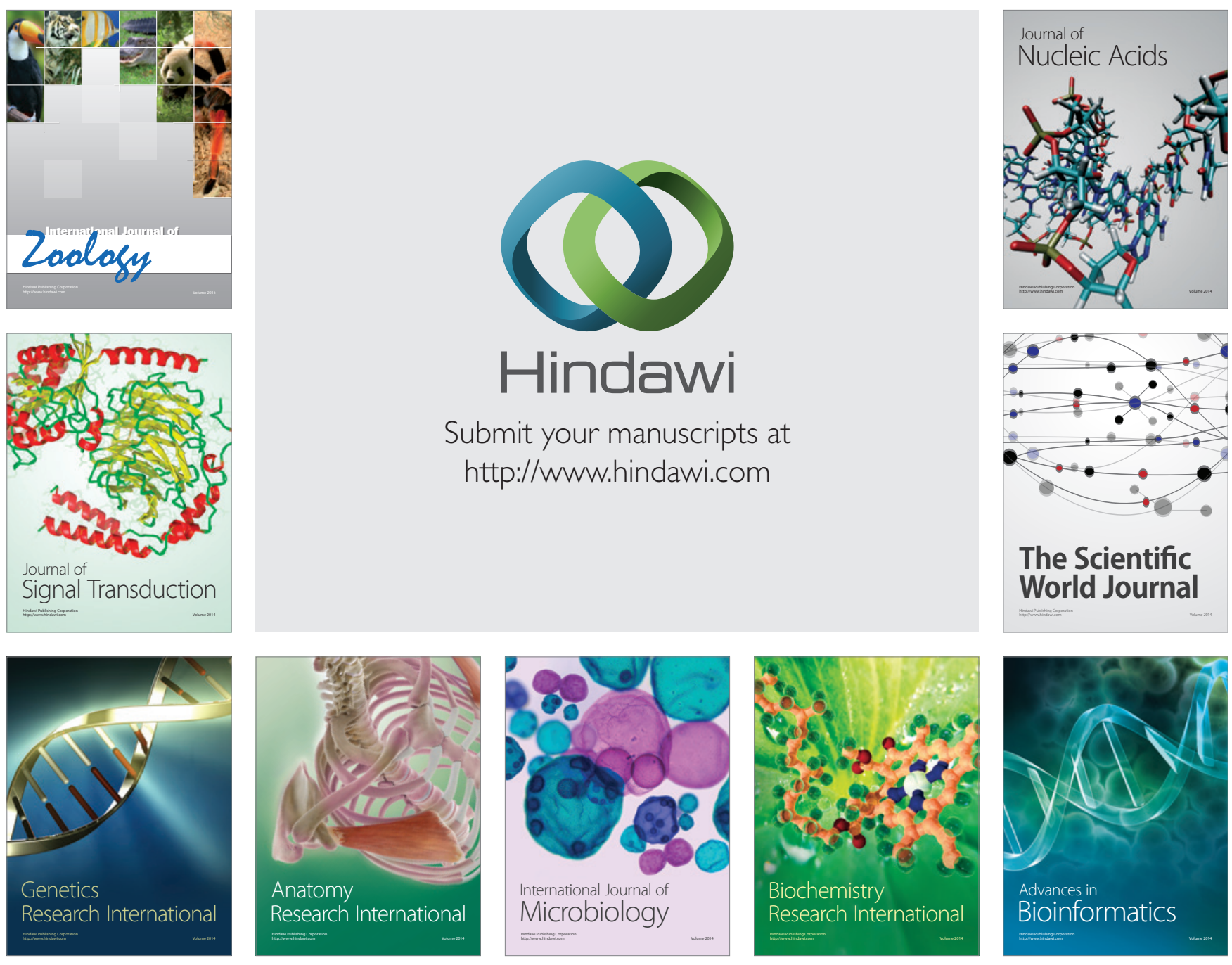

The Scientific World Journal
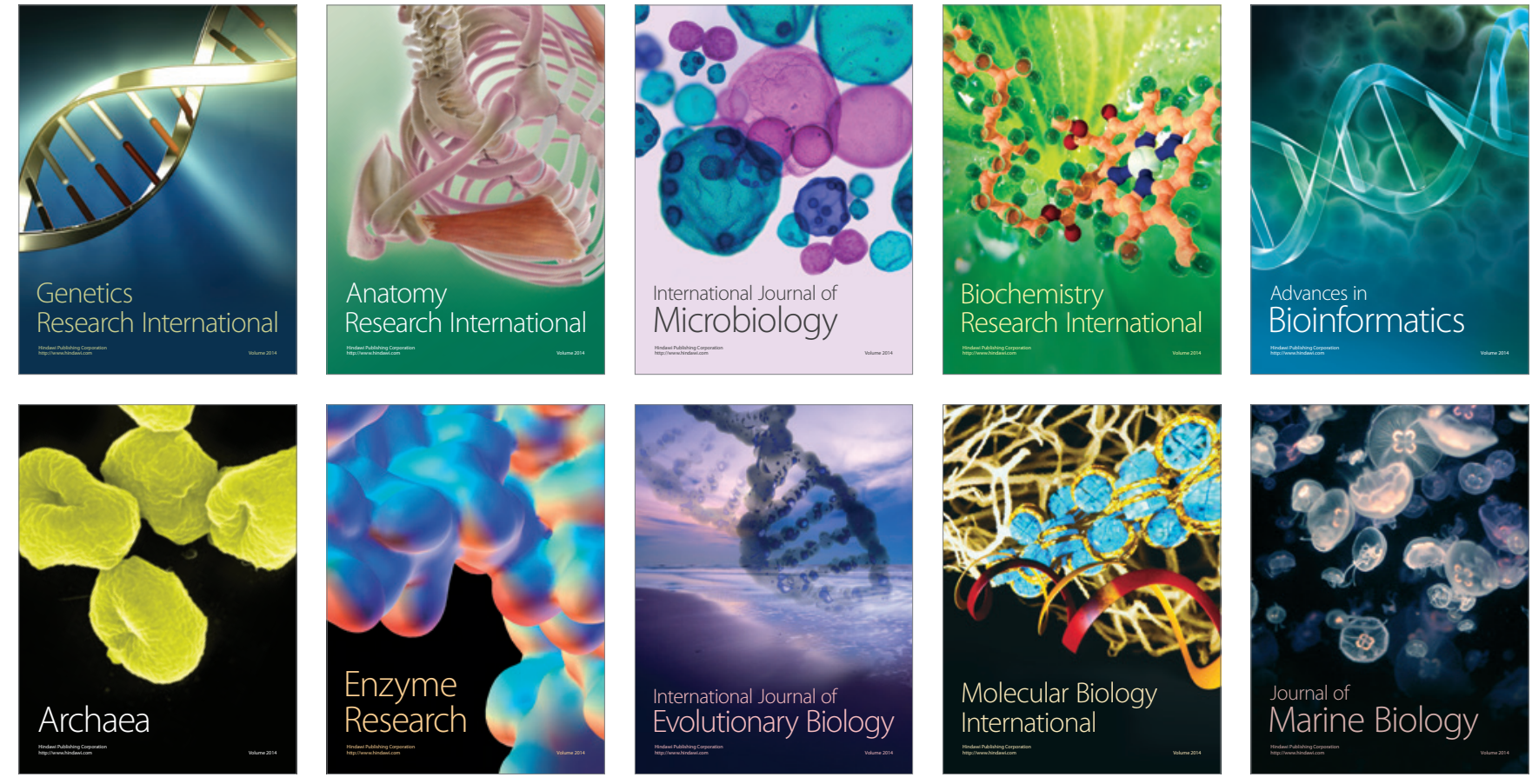